\title{
IMPLEMENTASI PRINSIP-PRINSIP MUAMALAH DALAM TRANSAKSI EKONOMI: ALTERNATIF MEWUJUDKAN AKTIVITAS EKONOMI HALAL
}

\author{
Dewi Maharani', Muhammad Yusuf ${ }^{2}$ \\ ${ }^{1}$ Universitas Muhammadiyah Banjarmasin, Email: dewimaharani922@gmail.com \\ ${ }^{2}$ Universitas Muhammadiyah Banjarmasin
}

\begin{abstract}
ABSTRAK
Penelitian ini bertujuan guna menjelaskan tentang prinsip-prinsip muamalah dalam transaksi ekonomi sebagaimana didalam Al-Quran dan Hadist. Aktivitas ekonomi halal menjadi peran penting dalam transaksi ekonomi pada kehidupan umat Muslim, dimana menjadi syarat utama sebagai salah satu esensi ajaran Islam. Aktivitas ekonomi yang dilakukan oleh seorang muslim bagian dari ibadah kepada Allah swt yang berada pada tatanan bingkai aqidah dan syariah. Ekonomi Islam bertujuan mencapai kebahagian di dunia dan akhirat melalui tatanan kehidupan, untuk membentuk kesetaraan antar umat manusia.
\end{abstract}

Kata-kata kunci : Implementasi: Prinsip; Muamalah; Ekonomi Halal

\section{ABSTRACT}

This study aims to explain the principles of Muamalah in economic transactions as in Al-Quran and Hadith. Halal economic activity plays an important role in economic transactions in Moslem life, which is the main requirement as one of the essences of Islamic teachings. Economic activities carried out by a Moslem are part of worship to Allah the Almighty who is in the framework of aqidah and sharia. Islamic economics aims to achieve happiness in the world and the hereafter through the order of life, to establish equality between humans.

Keywords: Implementation; Principl;, Muamalah; Halal Economy

\section{PENDAHULUAN}

Islam adalah agama yang diturunkan Allah swt kepada Nabi Muhammad saw sebagai pedoman hidup seluruh manusia hingga akhir zaman. Islam ajaran yang bersifat integral (menyatu) dan komprehensif (mencakup segala aspek), oleh karenanya semua aktivitas dalam Islam pada kehidupan seharu-hari termasuk aktivitas ekonomi harus berada pada tatanan bingkai aqidah dan syariah.

Aktivitas ekonomi yang berada pada tatanan bingkai aqidah dan syariah dimaksudkan bagian dari ibadah dan sarana mendekatkan diri 
kepada Allah swt serta menjalankan aktivitas ekonomi sesuai dengan aturan Al-Quran dan Hadist. Penyebab terlarangnya sebuah transaksi adalah disebabkan faktor-faktor sebagai berikut: haram zatnya (haram li-dzatihi), haram selain zatnya (haram li-ghairihi) dan tidak sah (lengkap) akadnya (Adiwarman, 2011:30).

Ketiga faktor penyebab transaksi diharamkan mengandung beberapa aktivitas ekonomi diantaranya tadlis (penipuan), gharar (tidak jelas objek transaksinya), ba'i najasy (Rekayasa pasar dalam demand) dan ikhtikar (rekayasa pasar dalam supply). Dalam pandangan ekonomi Islam uang dapat memenuhi kebutuhan pokok, sekunder dan tersier (daruriyah, hajiyah, dan tahsiniah) baik secara individu maupun komunitas dengan mengharapkan ridho Allah swt. Namun uang juga sebagai sarana seseorang menjadi kufur atau bersyukur dalam penggunaannya. Dalam Al -Quran fungsi sosial harta adalah menjadikan masyarakat yang etis dan egaliter.

Dalam kontek ini, untuk memperoleh harta didasarkan atas prinsip bahwa tidak seorangpun yang mempunyai hak memperoleh keuntungan atas pengorbanan orang lain, dan transaksi yang diperolehkan hanyalah transaksi yang didalamnya saling menguntungkan dengan cara adil (M Dawam Rahardjo, Etika Ekonomi dan Manajemen, 1990: 193). Sebagaimana firman Allah : Wahai orang-orang yang beriman, janganlah kamu saling memakan harta sesamamu dengan jalan yang batil, kecuali dengan jalan perniagaan yang berlaku dengan suka sama suka diantara kamu. Dan janganlah kamu membunuh dirimu; sesungguhnya Allah adalah Maha Penyayang kepadamu. "(QS. An-Nisa, 4:29). Ayat tersebut menjelaskan bahwa, untuk memperoleh harta harus dilakukan atas dasar saling menguntungkan, sehingga dalam pelaksanaannya tidak menimbulkan kerugian terhadap pihak lain dan sebaliknya harus menciptakan suasana yang rukun, saling tolong menolong, dan bantu membantu satu sama lain tanpa ada pemaksaan.

\section{METODE PENELIITIAN}

Kajian ini menggunakan metode penelitian analisis deskriptif. Jenis data yang digunakan adalah data sekunder, data dalam bentuk artikel, buku dan laporan penelitian serta sumber-sumber lain atau informasi yang relevan dengan kajian ini. Kemudian teknik pengumpulan data yang digunakan adalah studi literatur atau library research. Studi kepustakaan 
adalah kegiatan yang berkaitan dengan koleksi data perpustakaan, membaca, merekam, dan mengolah bahan penelitian.

Analisis data yang digunakan adalah deduktif yaitu menganalisis data penulis, dan bertolak dari kesimpulan atau pengetahuan yang bersifat umum, kemudian ditarik kesimpulan data fakta atau pendapat para ahli tentang suatu masalah tertentu, kemudian diuraikan pula aspek-aspek persamaan dan perbedaan tentang objek yang dikaji. Menurut Mestika Zed dalam bukunya yang berjudul Metode Penelitian Kepustakaan, ada empat langka penelitian kepustakaan yaitu; Pertama, menyiapkan alat perlengkapan. Kedua, menyusun bibliografi kerja. Ketiga, mengatur waktu. Keempat, membaca dan membuat catatan penelitian (Mestika Zed, 2014).

\section{HASIL DAN PEMBAHASAN $\backslash$}

1. Definisi, Prinsip-Prinsip Ekonomi Syariah

Ekonomi syariah merupakan suatu ilmu pengetahuan sosial yang mempelajari masalah-masalah ekonomi rakyat yang diilhami oleh nilai-nilai Islam (Mannan, 1992:15). Ekonomi syariah dikatakan sebagai bangunan perekonomian yang didirikan diatas landasan dasar-dasar Al Quran dan Hadist sesuai dengan masa (Muhammad Abdullah Al- Arabi (1980:11). Ibarat bangunan, Sistem ekonomi Syariah juga harus mempunyai fondasi yang berguna sebagai landasan untuk menopang segala macam kegiatan ekonomi untuk tujuan yang baik. Menurut Zainuddin Ali (2008), ekonomi syariah memiliki beberapa prinsip yang sangat mendasar, diantaranya:

a. Ihtikar (tidak melakukan penimbunan). Dalam bahasa Arab ihtikar artinya penimbunan. Ihtikar diartikan sebagai tindakan pembelian barang dagangan dengan tujuan untuk menahan atau menyimpan barang tersebut dalam jangka waktu yang lama, sehingga barang tersebut dinyatakan barang langka dan berharga mahal.

b. Tidak melakukan monopoli. Monopoli adalah kegiatan menahan keberadaan barang untuk tidak dijual atau tidak diedarkan di pasar, agar harganya menjadi mahal. Kegiatan monopoli merupakan salah satu hal yang dilarang dalam Islam, apabila monopoli diciptakan secara sengaja dengan cara menimbun barang dan menaikkan harga barang. 
c. Menghindari jual-beli yang diharamkan. Kegiatan jual-beli yang sesuai dengan prinsip Islam, adil, halal, dan tidak merugikan salah satu pihak adalah jual-beli yang sangat diridhai oleh Allah swt, karena sesungguhnya segala hal yang mengandung unsur kemungkaran dan kemaksiatan adalah haram hukumnya.

Dalam Islam kegiatan ekonomi bagian dari muamalah, persoalan muamalah yang terpenting pada substansi terhadap makna yang terkandung dan sasaran yang ingin dicapai dalam muamalah tersebut. Apabila muamalah dijalankan sesuai dengan kaidah dan prinsip dengan tujuan untuk kemaslahatan umat dengan menjauhkan dari hal-hal yang mudharat maka mualamalah yang dilakukan dapat di terima, sesuai dengan surat $A l$ Baqarah ayat 275 yang artinya "Allah telah menghalalkan jual beli dan mengharamkan riba" (Q.S Al-Baqarah (2):275).

Kaidah dan prinsip yang dimaksud demi tujuan kemaslahatan umat merupakan bagian dari satuan aktivitas ekonomi yang tidak bertentangan pada Alquran dan Hadits. Beberapa prinsip dalam Islam yang membedakan dengan sistem ekonomi lain dimaksud yaitu:

a. Tauhid

Ayat Alquran yang terkait pada prinsip tauhid didalam menjalankan ekonomi Islam terdapat pada Alquran surat Al-Ikhlas, yang artinya: "Katakanlah (Muhammad) ;Dia-lah Allah, yang Maha Esa, Allah adalah Tuhan yang bergantung kepada-Nya segala sesuatu. Dia tiada beranak dan tidak pula di peranakkan, dan tidak ada seorang pun yang setara dengan Dia" (Q.S Al- Ikhlas (112):1-4).

Pada surah Al-Ikhlas memberikan spirit kepada umat muslim dalam hal konteks bekerja, dimana seseorang melakukan segala bentuk usaha tetap harus bergantung kepada Allah Swt. Prinsip ini adalah dasar dari aktivitas yang dilakukan manusia. Quraish Shihab menyatakan bahwa tauhid mengantarkan manusia dalam kegiatan ekonomi untuk meyakini bahwa kekayaan apapun yang dimiliki oleh seseorang adalah milik Allah swt, dalam Al-Quran yang artinya: "Sesungguhnya sembahyangku, ibadahku, hidupku dan matiku hanyalah untuk Allah, Tuhan semesta alam"(Q.S 6 :163).

Hal ini akan melahirkan aktivitas ekonomi dengan parameter syariah sebagai landasan utama sehingga kehidupan umat muslim 
seimbang antara dunia dan akhirat, dimana seseorang tidak hanya mengharapkan keutungan materi saja namun juga mengejar akhirat untuk mendapatkan kehidupan yang lebih baik. Dengan menyadari prinsip tauhid maka bentuk eksploitasi terhadap sesama manusia tidak akan terjadi karena prinsip ini mampu mengendalikan hati dan pikiran seseorang terkhusus bagi pelaku usaha.

Prinsip ini berdampak positif bagi sistem ekonomi Islam dimana mengantisispasi terjadinya monopoli dan pemusatan kekuatan ekonomi pada satu orang atau kelompok usaha, terdapat pada firman Allah dalam surah Al-Hasyr (59:7) yang artinya: supaya harta itu jangan beredar diantara orang-orang kaya saja diantara kamu". Ayat ini menjadi sebuah tolak ukur tidak dibenarkannya monopoli pada berbagai kegiatan ekonomi yang berorientasi pada keuntungan semata tanpa melihat dan mempertimbangkan kemaslahatan umat.

b. Keadilan (Adl)

Kata adil berasal dari kata Arab "Adl" yang secara harfiyah bermakna sama. Menurut Kamus Bahasa Indonesia, adil artinya sama berat, tidak berat sebelah, tidak memihak, berpihak kepada yang benar dan sepatutnya. Keadilan merupakan pengakuan dan perlakuan yang seimbang antara hak dan kewajiban. Keadilan juga dapat berarti suatu tindakan yang tidak berat sebelah atau tidak memihak ke salah satu pihak, memberikan sesuatu kepada orang sesuai dengan hak yang harus diperolehnya. Bertindak secara adil berarti mengetahui mana yang hak dan kewajiban, mengerti mana yang benar dan yang salah, bertindak jujur dan tepat menurut peraturan dan hukum yang telah ditetapkan serta tidak bertindak sewenang-wenang.

Keadilan pada dasarnya terletak pada keseimbangan atau keharmonisan antara penuntutan hak dan menjalankan kewajiban. Berdasarkan segi etis, manusia diharapkan untuk tidak hanya menuntut hak dan melupakan atau tidak melaksanakan kewajibannya sama sekali. Sikap dan tindakan manusia yang semata-mata hanya menuntut haknya tanpa melaksanakan kewajibannya akan mengarah pada pemerasan atau perbudakan terhadap orang lain.

Al-Qur'an sebagai petunjuk moral yang komprehensif dan sempurna, untuk kebaikan manusia dan alam semesta dalam Surah 
yang artinya:"Sungguh, kami telah mengutus Rasul-rasul kami dengan bukti-bukti yang nyata, dan telah kami turunkan bersma mereka Al-Kitab dan neraca (keadilan) agar manusia dapat berlaku adil. Dan kami telah menciptakan besi yang mempunyai kekuatan hebat dan banyak manfaat bagi manusia, dan agar Allah mengetahui siapa yang menolong (Agama)-Nya dan rasul-rasul Nya walaupun Allah tidak dilihatnya. Sesunggunya Allah Maha kuat, Maha perkasa." (QS. al-Hadid [57] : 25).

Ayat diatas menegaskan bahwa Allah mengutus Rasul untuk menegakan keadilan di tengah-tengah masyarakat dan sekaligus memberantas kedzaliman. Dengan begitu, kesatuan umat, persaudaraan dan prinsip keadilan sosial ekonomi adalah unsur-unsur keadilan. Dalam al-Qur'an Allah dikatakan Maha Adil, dan bahwa dia menegakan keadilan atas dasar bahwa keadilan adalah sifat positif yang dimilikinya. Ditegaskan dalam al-Qur'an :

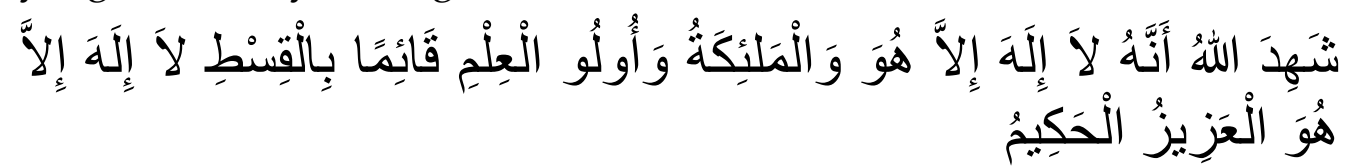

Artinya: "Allah menyatakan bahwasanya tidak ada Tuhan (yang berhak disembah) melainkan Dia, Yang menegakkan keadilan. Para malaikat dan orang-orang yang berilmu (juga menyatakan yang demikian itu). Tak ada Tuhan (yang berhak disembah) melainkan Dia, Yang Maha Perkasa lagi Maha Bijaksana." (Q.S. Ali Imran [3]: 18).

Ayat tersebut dengan jelas menegaskan bahwa Allah menyuruh untuk berbuat adil atau bahwa Dia adalah Pelaku keadilan. Kemudian, perintah Allah untuk mendirikan keadilan yang didasarkan atas kualitas monoteistik prinsip keesaan Tuhan yang sesuai dengan ajaran Islam (tauhid). Penegakan keadilan adalah merupakan perbuatan yang paling mendekati taqwa dalam diri manusia. Seperti ditegaskan dalam al-Qur'an yang artinya:"Hai orang-orang yang beriman, hendaklah kamu menjadi orang-orang yang selalu menjalankan (keadilan) karena Allah menjadi saksi dengan adil. Dan janganlah sekali-kali kebencian mu terhadap suatu kaum, mendorong kamu untuk berlaku tidak adil. Berlaku adilah karena adil itu lebih dekat kepada taqwa. Dan bertaqwalah kepada Allah, sesungguhnya Allah Maha mengeahui apa yang kamu kerjakan".(QS. al-Maidah [5] : 8). 
Islam menekankan prinsip keadilan dalam aktivitas ekonomi, karena didasarkan pada komitmen spritual dan konsep persaudaraan universal sesama manusia. Al-Quran secara eksplisit menekankan pentingnya keadilan dan persaudaraan tersebut. Menurut M. Umer Chapra (dalam tulisan M. Roem Syibly:2015), sebuah masyarakat Islam yang ideal mesti mengaktualisasikan keduanya secara bersamaan, karena keduanya merupakan dua sisi yang sama yang tak bisa dipisahkan. Dengan demikian, kedua tujuan ini terintegrasi sangat kuat ke dalam ajaran Islam sehingga realisasinya menjadi komitmen spritual (ibadah) bagi masyarakat Islam.

Komitmen Islam yang besar pada persaudaraan dan keadilan, menuntut agar semua sumber daya yang menjadi amanat suci Tuhan, digunakan untuk mewujudkan maqashid syari'ah, yakni pemenuhan kebutuhan hidup manusia, terutama kebutuhan dasar (primer), seperti sandang, pangan, papan, pendidikan dan kesehatan. Persaudaraan dan keadilan juga menuntut agar sumberdaya didistribusikan secara adil kepada seluruh rakyat melalui kebijakan yang adil dan instrumen zakat, infaq, sedekah, pajak, cukai ekspor-impor dan sebagainya.

Dalam aktivitas ekonomi halal, implementasi keadilan dalam fiqh muamalat melarang adanya unsur MAGHRIB, yaitu Maysir, Gharar, Haram, Riba, dan Bathil.

1) Maysir

Menurut bahasa maysir berarti gampang/mudah. Maysir satu makna dengan qimar secara harfiah artinya judi (spekulasi). Secara istilah maysir berarti mendapat keuntungan tanpa bekerja keras. Maysir dikenal dengan judi karena dalam praktiknya seseorang dapat memperoleh keuntungan dengan cara mudah. Islam mengajarkan tentang bagaimana usaha dan bekerja keras.

Larangan terhadap maysir sendiri sudah jelas ada dalam Q.S Al- Baqarah (219) yang artinya "Mereka menanyakan kepadamu (Muhammad) tentang khamar dan judi. Katakanlah, pada keduanya terdapat dosa besar dan beberapa manfaat bagi manusia. Tetapi dosanya lebih besar dari pada manfaatnya. Dan mereka menanyakan kepadamu (tentang) apa yang (harus) mereka infakkan. Katakanlah, kelebihan (dari apa yang diperlukan). Demikianlah Allah menerangkan ayat-ayat Nya 
kepadamu agar kamu memikirkan". Kemudian dalam Q.S Al Maidah (90) yang artinya "Wahai orang-orang yang beriman !Sesungguhnya minuman keras, berjudi, (berkurban untuk) berhala, dan mengundi nasib dengan anak panah, adalah perbuatan keji dan termasuk perbuatan setan. Maka jauhilah (perbuatan- perbuatan) itu agar kamu beruntung".

Dari ayat tersebut diatas jelas bahwasanya maysirlqimar di larang karena lebi hanyak mudharat-nya dari pada manfaatnya. Saat ini, instrument investasi yang ditawarkan oleh investor tidak sedikit yang mengandung spekulasi. Keuntungan yang didapat dalam menjalankan aktivitas ekonomi nya sangat mengandalkan spekulasi dimana keputusan seseorang dalam membeli dan menjual sahamnya didasari oleh perkiraan naik atau turun harga saham yang diperdagangkan.

2) Gharar

Gharar adalah istilah dalam hukum Islam yang artinya keraguan, tipuan, atau tindakan dengan tujuan merugikan orang lain. Gharar berupa akad yang mengandung unsur penipuan karena tidak adanya kepastian, baik mengenai ada atau tidaknya objek akad, besar kecilnya jumlah, maupun kemampuan menyerahkan objek yang disebutkan di dalam akad tersebut. Gharar menurut Imam an-Nawawi merupakan unsur akad yang dilarang dalam syariat Islam, sedangkan menurut Wahbah az-Zuhaili (1985:435) gharar memiliki makna sesuatu yang pada lahirnya menarik, tetapi tercela secara terselubung.

Gharar juga dikatakan sebagai transaksi yang dilakukan namun masih belum jelas barangnya atau tidak berada dalam kuasanya. Dapat dikatakan bahwa konsep gharar bermakna ketidaktentuan dan ketidakjelasan sesuatu transaksi yang dilaksanakan. Islam melarang adanya aktivitas ekonomi yang mengandung unsur gharar, dalam Q.S An-Nisa (29), yang artinya "Wahai orang-orang yang beriman! Janganlah kamu saling memakan harta sesamamu dengan jalan yang batil (tidak benar), kecuali dalam perdagangan yang berlaku atas dasar suka sama suka diantara kamu. Dan janganlah kamu membunuh dirimu. Sungguh Allah Maha Penyayang kepadamu". Dari ayat ini jelas, larangan terhadap jual beli yang tidak benar dengan mengandung unsur gharar. 
3) Haram

Aktivitas ekonomi yang dijalankan apabila objek yang diperjualbelikan haram, maka transaksi nya menjadi tidak sah. Misalnya jual beli khamr, dan lain-lain. Dalam Ushul fiqih, muamalah menetapkan standar dalam penentuan halal dan haram dalam aktivitas ekonomi, semuanya kegiatan muamalah di perbolehkan kecuali yang jelas dilarang Allah Swt. Menurut Muhammad (2006) mengemukakan bisnis yang diharamkan antara lain produksi dan pedagangan alkohol, obat terlarang, bisnis patung, bisnis barang-barang haram, bisnis pelacuran, bersifat gharar (tidak pasti) dan menggunakan bisnis bagi hasil yang dilarang.

4) Riba

Riba sangat dilarang dalam agama QS. Ar Rum (39), artinya: "Dan sesuatu riba (tambahan) yang kamu berikan agar dia bertambah pada harta manusia, maka riba itu tidak menambah pada sisi Allah. Dan apa yang kamu berikan berupa zakat yang kamu maksudkan untuk mencapai keridaan Allah, maka (yang berbuat demikian) itulah orang-orang yang melipat gandakan (pahalanya)".

Riba juga digambarkan sebagai suatu yang buruk dan balasan yang keras kepada orang Yahudi yang memakan riba. Allah berfiman dalam QS. An Nisa (160-161)"Maka disebabkan kezaliman orang-orang Yahudi, Kami haramkan atas mereka (memakan makanan) yang baik-baik (yang dahulunya) dihalalkan bagi mereka, dan karena mereka banyak menghalangi (manusia) dari jalan Allah, dan disebabkan mereka memakan riba, padahal sesungguhnya mereka telah dilarang daripadanya, dan karena mereka memakan harta orang dengan jalan yang batil. Kami telah menyediakan untuk orang-orang yang kafir di antara mereka itu siksa yang pedih".

Riba juga diharamkan karena terkait pada suatu tambahan yang berlipat ganda, tertuang dalam QS. Ali Imran (130) yang artinya: "Hai orang-orang yang beriman, janganlah kamu memakan riba dengan berlipat ganda dan bertakwalah kamu kepada Allah supaya kamu mendapat keberuntungan."Riba juga menunjukkan betapa kerasnya Allah dalam mengharamkan riba. QS. Al Baqarah (278-279) yang artinya "Hai orang-orang yang beriman, bertakwalah kepada Allah dan tinggalkan sisa riba (yang belum dipungut) jika kamu orang-orang yang 
beriman. Maka jika kamu tidak mengerjakan (meninggalkan sisa riba), maka ketahuilah, bahwa Allah dan Rasul-Nya akan memerangimu. Dan jika kamu bertobat (dari pengambilan riba), maka bagimu pokok hartamu; kamu tidak menganiaya dan tidak (pula) dianiaya".

Dari beberapa ayat di atas jelaslah bahwa riba sangatlah dilarang karena riba salah satu dari tujuh dosa besar yang telah ditetapkan oleh Rasulullah SAW. Dalam sebuah hadits: Dari Abi Hurairah ra berkata bahwa Rasulullah SAW bersabda, "Jauhilah dari kalian tujuh hal yang mencelakakan". Para sahabat bertanya,"Apa saja ya Rasulullah?". "Syirik kepada Allah, sihir, membunuh nyawa yang diharamkan Allah kecuali dengan hak, makan riba, makan harta anak yatin, lari dari peperangan dan menuduh zina." (HR. Muttafaq alaihi).

c. Kebebasan dan Kebolehan

Dalam muamalah pada dasarnya, setiap persyaratan/ perjanjian (transaksi) hukumnya dihalalkan. Di antara dalil yang menunjukkan kaidahnya pada Q.S Al-Isra (34) yang artinya : Dan janganlah kamu mendekati harta anak yatim, kecuali dengan cara yang lebih baik (bermanfaat) sampai ia dewasa dan penuhilah janji; sesungguhnya janji itu pasti diminta pertanggungan jawabnya.

Dan Sabda Nabi Muhammad SAW: Berdamai dengan sesama muslimin itu diperbolehkan kecuali perdamaian yang menghalalkan suatu yang haram atau mengharamkan suatu yang halal. Dan kaum Muslimin harus memenuhi syarat-syarat yang telah mereka sepakati kecuali syarat yang mengharamkan suatu yang halal atau menghalalkan suatu yang haram (HR. Bukhari).

Dari ayat di atas menjelaskan bahwasanya kebebasan dan kebolehan dalam setiap perjanjian yang sudah disepakati dalam hal aktivitas ekonomi dibolehkan sesuai dengan Al Quran dan Hadist. Kaidah ini memberikan keseimbangan dalam berkreasi, berinovasi, bertransaksi namun memiliki batas dan tidak bertentang pada ajaran agama.

d. Kemashlahatan

Prinsip kemaslahatan bertitik tolak dari kaidah dalam 
berprilaku bahwa mengambil manfaat dan meninggalkan kemudaratan atau mendatangkan suatu kebaikan/faedahnya. Dalam hukum Islam kemashlahatan memiliki peranan penting karena dianggap sebagai tujuan akhir dari syariat Islam. Dalam aktivitas ekonomi saat ini, mengedapankan kemaslahatan sangat efektif untuk mensyiarkan pesan-pesan Allah Swt dalam hal bermuamalah sehingga menghasilkan aktivitas ekonomi halal bagi umat Islam.

Dalam konsep Islam, yang dikatakan manusia yang terbaik adalam manusia yang mampu memberikan manfaat kepada orang banyak. Hal ini juga sebagai bukti bahwasannya Islam adalah agama yang memberikan rahmatnya bagi alam semesta. Bila di kaitkan dengan aktivitas ekonomi, saat kita menjalankan bisnis dalam penyediaan berbagai kebutuhan umat manusia tidak serta merta untuk mencari keuntungan semata, namun kita dituntut untuk membantu orang lain dalam memenuhi kebutuhannya.

e. Ta'awun (Tolong menolong)

Prinsip ini memiliki arti saling membantu antar sesama manusia yang diarahkan sesuai prinsip tauhid, terutama dalam peningkatan kebaikan dan ketakwaan. Sebagai makhluk sosial, manusia tidak dapat memenuhi kebutuhan hidupnya sendiri namun membutuhkan bantuan orang lain. Dengan begitu, sikap saling tolong menolong dibutuhkan untuk membantu meringankan beban satu sama lain. Karena antara manusia saling membutuhkan, tidak ada seorang pun manusia yang tidak membutuhkan pertolongan dari orang lain. Maka sangalah tidak pantas bila seseorang memiliki sifat sombong dan merendahkan orang lain karena merasa dirinya lebih mulia. Pada hakikatnya semua makhluk adalah yang lemah.

Islam menekankan untuk senantiasa tolong menolong tidak peduli apa suku, ras, dan agama seseorang. Rasulullah SAW mencontohkan bagaimana membantu orang yang membutuhkan pertolongan tanpa melihat latar belakang suku, ras, maupun agamanya. Misalnya kisah kebaikan Rasulullah kepada wanita buta Yahudi yang pada setiap hari selalu mencaci maki Rasulullah. Tolong menolong merupakan kebiasaan mulia yang di bangun sebagai bentuk kepedulian terhadap sesama manusia, Q.S Al-Maidah (2) tentang saling 
tolong menolong yang penting untuk kita perhatikan, yang artinya:"Dan tolong-menolonglah kamu dalam mengerjakan kebajikan dan takwa, dan jangan tolong-menolong dalam perbuatan dosa dan permusuhan. Bertakwalah kepada Allah, sesungguhnya Allah sangat berat siksaan-Nya".

Ayat di atas menjelaskan tentang bagaimana tolong menolong dapat menumbuhkan rasa solidaritas kita kepada sesama, terutama kepada sesama muslim yang sedang membutuhkan bantuan. Dalam aktivitas ekonomi tolong menolong antar umat dalam bentuk shadaqah, infaq, zakat dll. Aktivitas tersebut memiliki dampak positif yaitu dalam hal perbaikan ekonomi masyarakat, dimana terjadinya pendistribusian pendapatan dan kekayaan masyarakat secara lebih baik. Hal ini juga dikatakan sebagai bentuk pengayoman kepada masyarakat ekonomi lemah dengan cara berbagi sehingga terjadinya pemerataan pendapatan.

2. Konsep Aktivitas Ekonomi dalam Al-Qur'an dan Hadits

Berdasasrkan penjelasan di atas, jelas bahwasannya Islam mengatur aktivitas ekonomi didalam Al- Quran dan Hadits. Dimana dijelaskan bahwasanya aktivitas ekonomi itu dibolehkan terkecuali melanggar aturan Allah Swt yang telah ditetapkan di dalam Al- Quran dan Hadits. Biasanya larangan yang dimaksud adalah melanggar kaidah-kaidah atau prinsipprinsip dalam bermuamalah, seperti tentang halal atau haramnya aktivitas ekonomi yang dilakukan

Berdasarkan penjelasan diatas, jelas bahwasannya Islam mengatur aktivitas ekonomi didalam Al- Quran dan Hadist. Dimana dijelaskan bahwasanya aktivitas ekonomi itu dibolehkan terkecuali melanggar aturan Allah Swt yang telah ditetapkan di dalam Al- Quran dan Hadist. Biasanya larangan yang dimaksud adalah melanggar kaidah-kaidah atau prinsipprinsip dalam bermuamalah, seperti tentang halal atau haramnya aktivitas ekonomi yang dilakukan.

Menciptakan Kesejahteraan Agama dan Sosial, Agama Islam adalah agama yang damai, untuk itu dalam aspek ekonomi dimana jika ada orang yang berniaga dan ia pernah beraniaya terhadap kita pada saat sebelumnya, Allah melarang hal aniaya tersebut. Semua ini membuktikan bahwa Islam sangat mengedepankan aspek kesejahteraan dalam agama dan juga sosial. Ekonomi Islam berfungsi sosial, Islam jika dilihat dari peribahasa adalah 
muamalah, perhubungan hidup yang dipertalikan oleh materi dan inilah yang dinamakan ekonomi. Muamalah adabiyyah ialah pergaulan hidup yang dipertalikan oleh kepentingan moral, rasa kemanusiaan, dan ini yang dimanakan sosial.

Berdasarkan pengertian yang luas ini, Ali Fikri mengarang beberapa jilid buku yang berjudul Al Muamalah, ia memandang bahwa soal ekonomi dan muamalah maddiyah sangat sukar, tetapi memegang peranan penting sekali, karena berhubungan dengan benda dan uang yang sangat dicintai dan berkuasa di hati manusia. Ekonomi itulah sumber segala pekerjaan, pusat dari susunan alam, dan dengan ekonmi pula manusia mencapat tingkat yang paling tinggi dari kemajuan dan kebahagiaan.

\section{SIMPULAN}

Di dalam aktivitas ekonomi Islam prinsip-prinsip yang dijalankan tertuang di dalam Alquran dan Hadist, guna mewujudkan kegiatan ekonomi secara halal. Kegiatan ekonomi boleh dijalankan tanpa harus menimbulkan mudharat bagi orang banyak dan tidak ada pelarangan didalam Al Quran dan hadist. Konsep yang ditawarkan oleh ekonomi Islam bertujuan memberikan keseimbangan dalam kehidupan manusia baik secara individu maupun makhluk sosial.

Kegiatan ekonomi dalam Islam memberikan batasan-batasan untuk melakukan aktivitas ekonomi dengan dilandasi oleh tauhid, adil, kebebasan, kemashlahatan dan ta'awun. Didalam Alquran dan Hadist juga melarang adanya Maysir, Gharar, Haram, Riba, dan Bathil. Aktivitas ekonomi ini akan merusak keseimbangan hidup manusia karena memberikan efek negatif dan menggangu kemaslahatan.

\section{DAFTAR RUJUKAN}

Adimarwan, A. Karim. 2011. Bank Islam "Analisa Fiqih dan Keuangan". Jakarta: PT. Rajagrafindo Persada

Ahmad Muhammad Al-assal dan Fathi Ahmad Abdul Karim. 1980. Sistem

Ekonomi Islam, Prinsip-Prinsip dan Tujuan-Tujuannya. Surabaya: PT Bina Ilmu.

Kamus Besar Bahasa Indonesia. [Online]. Tersedia di kbbi.kemdikbud.go.id /entri/religius.

Fikri, Ali. Al-Muamalat al-maddiyah wa al-adabiyah, Terj. Ali Fikri, Mesir: Mushtafa Al-Babiy Al-Halabiy, 1356. 
Kementerian Agama, R. (2007). Al-Qur'an Terjemahan. In Al-Qur'an Terjemahan.

Madjid, S. S. (2018). PRINSIP-PRINSIP (ASAS-ASAS) MUAMALAH. JURNAL HUKUM EKONOMI SYARIAH. https://doi.org/10.2661 8/j-hes.v2i1.1353

Mestika Zed. (2014). Metode Penelitian Kepustakaan (3rd ed.). Yayasan Pustaka Obor Indonesia.

Mursal, M. (2017). IMPLEMENTASI PRINSIP-PRINSIP EKONOMI SYARIAH: Alternatif Mewujudkan Kesejahteraan Berkeadilan. JURNAL PERSPEKTIF EKONOMI DARUSSALAM. https://doi.org/ 10.24815/jped.v1i1.6521

M. A Mannan. 1992. Ekonomi Islam: Teori dan Praktek. Jakarta: PT. Intermasa.

M. Dawam Rahardjo, Etika Ekono/mi dan Manajemen, Cet I, (Yogyakarta: PT Tiara Wacana Yogya,1990), 193

Syibly, M. R. (2015). KEADILAN SOSIAL DALAM KEUANGAN SYARIAH. Millah. https://doi.org/10.20885/millah.vol15.iss1.art4

Zainuddin Ali. 2008. Hukum Ekonomi Syariah. Jakarta: Sinar Grafika Offset. 